\title{
Ewa Puzio
}

University of Szczecin

e-mail:ewa.puzio@usz.edu.pl

ORCID: 0000-0003-2480-9579

\section{THE DEVELOPMENT OF SHARED MOBILITY IN POLAND USING THE EXAMPLE OF A CITY BIKE SYSTEM}

\section{ROZWÓJ WSPÓŁDZIELONEJ MOBILNOŚCI W POLSCE NA PRZYKLADZIE SYSTEMU ROWERU MIEJSKIEGO}

DOI: $10.15611 / \mathrm{pn} .2020 .2 .13$

JEL Classisfication: O18, R41

Summary: The constant influx of people to cities is associated with the increase in the transport needs of urban residents. The consequences of these phenomena are the challenges posed to local governments in shaping urban mobility towards sharing transport means. The article discusses the development of shared mobility in Poland based on the example of a city bike system. The undertaken considerations are presented on the basis of the results of secondary research against the background of changes in the attitudes of the transport behaviour of residents consisting in the growing interest in the use of alternative methods of mobility. The aim of the paper is to indicate the factors influencing the development of shared mobility in Poland with particular emphasis on the city bike system. In order to achieve this goal, the desk research method was used, taking into account the available literature and results of secondary research on shared mobility and bike sharing services in Poland. The territory of Poland was used as the research area.

Keywords: shared mobility, urban bike system, transport.

Streszczenie: Nieustanny napływ ludności do miast wiąże się ze zwiększeniem potrzeb transportowych mieszkańców miast. Następstwem tych zjawisk są wyzwania stawiane samorządom dotyczące kształtowania mobilności miejskiej w kierunku współdzielenia środków transportu. W artykule omówiono rozwój współdzielonej mobilności w Polsce na przykładzie systemu roweru miejskiego. Podjęte rozważania przedstawiono na podstawie wyników badań wtórnych na tle zmian postaw zachowań komunikacyjnych mieszkańców polegających na rosnącym zainteresowaniu wykorzystaniem alternatywnych metod poruszania się. Celem artykułu jest wskazanie czynników wpływających na rozwój współdzielonej mobilności w Polsce ze szczególnym uwzględnieniem systemu roweru miejskiego. Posłużono się metodą desk research, uwzględniając dostępną literaturę i wyniki badań wtórnych poświęconych współdzielonej mobilności oraz usług bike sharingu w Polsce. Obszarem badawczym było terytorium Polski.

Słowa kluczowe: współdzielona mobilność, system roweru miejskiego, transport. 


\section{Introduction}

Shared mobility should be understood as a new kind of mobility, consisting in the temporary use of vehicles such as bicycles, gopeds, $\mathrm{UTOs}^{1}$, scooters and cars that are rented using mobile applications, used individually, and after the journey the vehicle can be rented again by another person. In Poland the number of shared means of transport amounts to 37 000, with bicycles being the dominant group (24 700, including almost 1800 devices with electric assistance) available locally since 2008 . Self-service urban bike stations in Poland can be used by residents of 67 cities. It is estimated that 2.200 .000 people use bike sharing services in the country (based on the number of accounts created in the operator's application in 2019) [Jędrzejewski, Domaszewicz 2019]. In coming years, a significant increase in shared mobility is expected in response to the growing transport problems in cities and the negative impact of transport on the urban environment, such as traffic accidents, traffic noise, air pollutant emissions, transport congestion, and transport investment [Nosal, Starowicz 2010]. Many cities have adopted targets to foster more sustainable mobility [Ramos et al. 2020]. Part of efforts made by cities is to alter transport behaviour to more multimodal alternatives and to promote smart solutions to reduce private car use [Docherty, Marsden, Anable 2018].

The aim of the article is to indicate the factors influencing the development of shared mobility in Poland with a particular emphasis on the urban bicycle system. In order to achieve this goal, the desk research method was used, taking into account the available literature and results of secondary research on shared mobility and bike sharing services in Poland.

\section{Transport problems of Polish cities}

In today's large cities and surrounding agglomerations, the aim is to increase the share of both public transport and pedestrian and bicycle traffic [Sulmicki 2017]. The reasons for this phenomenon include: the need to ensure an effective transport system, the reduction of emissions of pollutants harmful to health and the environment, changing the public communication behaviour of the inhabitants, limiting the number of cars and the intensity of car traffic [Sulmicki 2017]. The recent popularity experienced by shared mobility services is due to advances in technology (mainly smartphones, positioning systems, and mobile payment), economic changes, and social and environmental concerns related to vehicle ownership and urban living [Shaheen et al. 2017].

One of the tasks of local authorities is to encourage city dwellers to gradually give up the idea of having their own cars and use other, alternative means of transport.

${ }^{1}$ The so-called personal transport device is a single-person electric vehicle designed to be driven exclusively by the user (in Poland there are no regulations concerning the UTO, the Ministry of Infrastructure is working on an amendment to the Act on Road Traffic Law). 
The urban mobility strategy is strongly influenced by the functional and spatial structure of a city [Tarkowski 2016]. Suburbanisation is an important process which influences the intensification of traffic in cities and generates additional transport problems, while the attempts of local governments to develop a technical and social infrastructure is too slow and too expensive. Suburbanisation has led to a situation where the distances between the place of residence, work and satisfaction of other basic needs have significantly increased [Gadziński, Goras (eds.) 2019]. Due to the lack of a public transport services tailored to the needs of the inhabitants, the car is the most frequently chosen means of transport for the inhabitants of peripheral areas. This situation brings a yearly increase in the motorization index, which is presented in Figure 1.

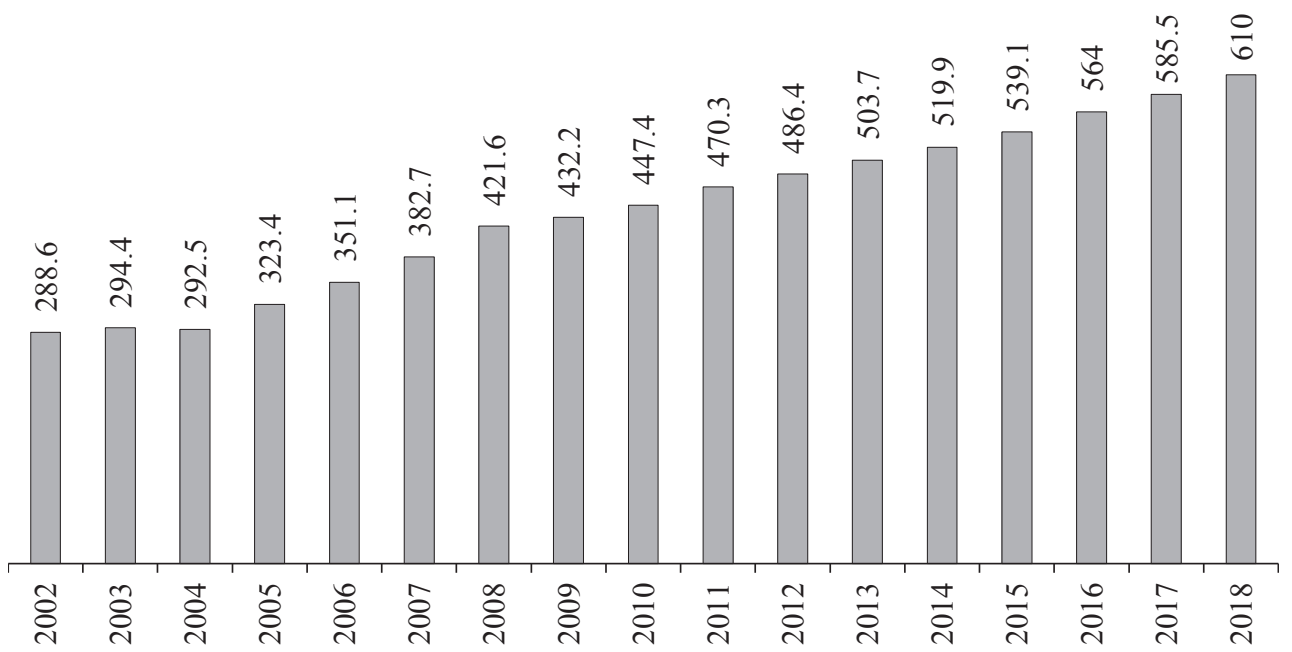

Fig. 1. Number of registered passenger cars in Poland per 1000 inhabitants

Source: own elaboration based on [Główny Urząd Statystyczny 2019].

As can be seen in Figure 1, in 2018 the number of passenger cars per 1000 inhabitants was 610 . Compared to 2017, the motorisation index increased by $4.18 \%$, while over the last 16 years the number of passenger cars per 1000 inhabitants has more than doubled.

Due to the dynamically growing use of passenger cars as the main means of transport, local governments decided to shorten some of the routes, reduce the frequency of some journeys made by public transport vehicles, or eliminate unprofitable routes [Gadziński, Goras (eds.) 2019]. These activities brought a decrease in the accessibility of public transport services for the inhabitants, and the result was further expansion of individual motorisation, which was associated with the costs incurred by cities for the development of a road infrastructure. Urban traffic 
organisers strive to improve the transport system by introducing bans and certain restrictions for people using passenger cars, e.g. restrictions on accessibility for individual car use in city centres, creation of paid parking zones and charges for using the existing transport infrastructure in cities [Szoltysek 2011, p. 8].

The growing transport needs of the inhabitants, the dynamically growing urban areas and the change of lifestyle of the inhabitants pose new challenges for local governments in terms of shaping urban mobility. According to the National Urban Policy 2023, an important element of the transport policy is related to planning and carrying out comprehensive actions aimed at changing the transport behaviour of the inhabitants [Krajowa Polityka... 2015]. Actions taken by local authorities must be aimed at reducing the role of the passenger car in favour of alternative means of transport [Krajowa Polityka... 2015]. One of the postulates regarding the image of urban transport in the future, included in the White Paper entitled: "Plan for the creation of a single European transport area - striving to achieve a competitive and resource-efficient transport system "is the provision of high-quality urban mobility services with economical resource management, i.e. using environmentally friendly means of transport, taking care of available infrastructure and striving to modernize it while limiting the negative impact of transport on the environment [The White Paper... 2011].

\section{Shared mobility in Poland}

The means of achieving the objective contained in the National Urban Policy 2023, as well as in the White Paper, is to ensure an efficient public transport system in urban areas. The result of these measures should involve a reduction in the share of private cars in cities or the total move away from the possession of a passenger car in favour of the use of shared means of transport. An institutional condition, which

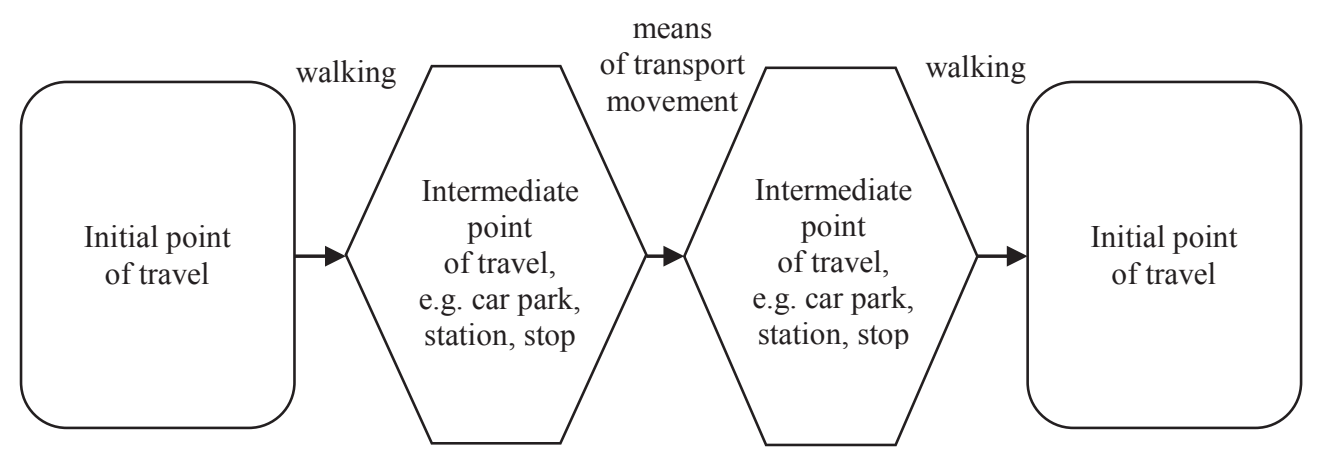

Fig. 2. Scheme of non-walking travel in urban areas

Source: own elaboration based on [Chamier-Gliszczyński 2015]. 
is an advantage and at the same time conducive to the implementation of the strategy of balancing urban mobility, involves the popularization by local governments of shared means of transport such as bicycles, gopeds, UTOs, scooters and light electric vehicles [Tarkowski 2016]. These vehicles are most often used to cover the first or last mile of a journey. Figure 2 shows a diagram of non-walking travel in urban areas, which can be implemented with the use of shared means of transport.

Modern cities strive for the effective use of various means of transport and the creation of co-modality between different types of public transport (train, tram, metro, bus, taxi) and means of individual transport (car, motorcycle, bicycle, walking, scooter, UTO, e-scooter) [Krysiuk, Brdulak, Banak 2015]. Factors influencing the development of shared mobility in Poland include:

- increase in the environmental awareness of city dwellers,

- achieving the European Union's transport policy objective of promoting a low-carbon economy,

- leading a healthy lifestyle,

- the current fashion by city dwellers,

- moving away from ownership in favour of shared use (no additional costs related to parking, service or insurance),

- development of new technologies,

- the growing number of inhabitants of cities, resulting in an improved transport system in cities,

- development of urban space in accordance with the needs of city residents (e.g. development of a bicycle infrastructure).

Shared mobility also helps to balance urban transport. Its main benefits include [Jędrzejewski, Domaszewicz 2019]:

- $\quad$ space saving - less need for parking spaces, because one vehicle is used by many users and is often on the move,

- less car traffic - due to the wide range of alternative means of transport, a certain percentage of the population living in cities either renounce owning their own car or use a private vehicle only to travel outside the city,

- lower mobility expenses of residents - users of shared vehicles incur costs only during the duration of the service, while owners of passenger cars incur much higher costs, e.g. for fuel, insurance, technical maintenance, repairs, parking zones, etc.,

- less emissions of $\mathrm{CO}_{2}$ - shared means of transport are usually low-carbon or zero-carbon emission (bicycles),

- solving the problem of the first and last mile - using e.g. bicycles,

- e-scooter or scooters to cover the routes: home - metro station, bus stop work, etc.,

- greater convenience - access to different means of transport with one mobile application, 
- greater flexibility - shared mobility as another of the city's mobility methods that can be chosen by residents (along with walking, public transport, private car or taxi).

Shared mobility is also a challenge for city authorities. Table 1 shows the challenges and dilemmas for the introduction and use of different means of transport.

Table 1. Bike, motorized scooter, scooter and car-sharing in the urban environment - challenges

\begin{tabular}{|c|c|c|c|}
\hline City bike & Motorised scooter & Scooter & Carsharing \\
\hline $\begin{array}{l}\text { - public subsidies, } \\
\text { - creating a local monopoly, } \\
\text { - short-term contracts, } \\
\text { - incentive schemes for } \\
\text { operators, } \\
\text { - improvement of the quality } \\
\text { and technical condition of the } \\
\text { station/bike, } \\
\text { - decisions concerning the } \\
\text { implementation of station/ } \\
\text { mixed models, } \\
\text { - existing cycling infrastructure, } \\
\text { - the rules of GDPR }\end{array}$ & $\begin{array}{l}\text { - } \text { inadequacy of law, } \\
\text { - security issues, } \\
\text { areas for scooters } \\
\text { (gopeds) to be left, } \\
\text { - cooperation of local } \\
\text { governments with } \\
\text { the operators, } \\
\text { - organisation of } \\
\text { services, } \\
\text { - the rules of GDPR }\end{array}$ & $\begin{array}{l}\text { - the need to give } \\
\text { priority to scooters } \\
\text { in the city, } \\
\text { - relocating the } \\
\text { fleet, } \\
\text { - construction of } \\
\text { infrastructure for } \\
\text { charging scooters, } \\
\text { - cooperation of } \\
\text { local governments } \\
\text { with the operators, } \\
\text { - the rules of GDPR }\end{array}$ & $\begin{array}{l}\text { - creating a local } \\
\text { monopoly, } \\
\text { - cooperation of local } \\
\text { governments with } \\
\text { the operators, } \\
\text { - favouring vehicles } \\
\text { rented per minute in } \\
\text { the city, } \\
\text { - support by the } \\
\text { business community, } \\
\text { - the rules of GDPR }\end{array}$ \\
\hline
\end{tabular}

Source: own elaboration based on [Jędrzejewski, Domaszewicz 2019].

An important challenge facing the local governments of modern cities is also related to the efficient use of space around existing urban buildings, with a preference for public, shared and non-motorised transport. In order to improve the quality of public space in cities, areas with an excessive road infrastructure need to be regained, which will create conditions that will encourage people to live in cities, not in peripheral areas, and will improve the quality of life of city dwellers [Sulmicki 2017].

\section{Urban bikes as a shared mode of transport}

Urban bicycles appeared in Poland in 2008 in Kraków and were the first shared means of transport introduced in the country. The urban bike system on the Vistula River was developed within the framework of the EU Civitas Carvellprogramme. Initially, the system consisted of 12 stations and 100 bicycles (BikeOne) [Dominiak 2016]. The continuous need to develop urban bike systems is evidenced by the numbers, which are growing every year. In 2019, bike sharing services were used by 2.2 million users, who could rent 24.7 thousand shared bikes at 3 thousand stations, while the revenues of operators amounted to PLN 93 million [Jędrzejewski, Domaszewicz 2019]. The most important directions of activities in the field of popularisation and development of cycling by local governments include [Kos, Krawczyk, Tomanek 2018]: 
- the development of cycle paths and routes,

- the development of public bicycle systems (bikesharing),

- the promotion of sustainable mobility by bicycle.

The whole Poland is undergoing an intensive development of the cycling infrastructure. Local governments are investing in hundreds of kilometres of bicycle paths, which are built in cities as an infrastructure for city bike systems and outside the city near places attractive for tourists (biking tourism). Figure 3 shows the total length of cycle paths in Poland in the period 2011-2018 (in km).

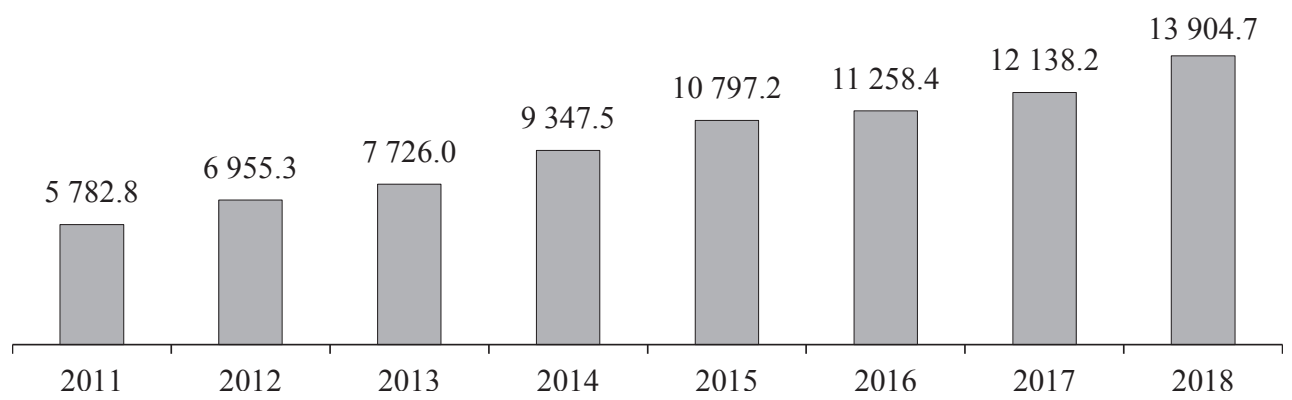

Fig. 3. Total length of bicycle paths in Poland in 2011-2018 (in km)

Source: own elaboration based on [Główny Urząd Statystyczny 2019].

As can be seen in Figure 3, the length of bicycle paths in Poland is increasing year by year. In 2018 the total length of bicycle paths was $13904.7 \mathrm{~km}$ (an increase by $1766.5 \mathrm{~km}$ compared to 2017). It is interesting that the longest cycling route in Poland is the Eastern Bicycle Route Green Velo, which is almost $2000 \mathrm{~km}$ long. It runs through the five provinces located in the eastern parts of the country [Przebieg szlaku 2017]:

- Warmia and Mazury (approx. $420 \mathrm{~km}$ ),

- Podlaskie (approx. $592 \mathrm{~km}$ ),

- Lubelskie (approx. $351 \mathrm{~km}$ ),

- Podkarpackie (approx. $428 \mathrm{~km}$ ),

- Świętokrzyskie (approx. $190 \mathrm{~km}$ ).

Warsaw is the city with the most developed cycling infrastructure - in 2018 the total length of cycling paths was $590 \mathrm{~km}$. The city has focused on the development of bicycle paths due to the growing bicycle traffic (as much as $20 \%$ every year) [Warszawa lideruje... 2017]. Warsaw also has one of the largest city bike systems in Europe (Veturilo). Users have at their disposal over 390 stations and over 5.700 bicycles (including 60 children's bicycles, 45 tandems and 110 electric bicycles) [Veturilo... 2019].The system was officially launched in 2012. NextbikePolska has been the system's contractor and operator since its inception. The Capital City of Warsaw fully finances the system, and user fees are returned to the city budget. 
The Warsaw Public Bike is particularly popular among students, as evidenced by the high occupancy rate on the following routes: Pole Mokotowskie subway - Banacha street (UW campus) and Trojdena street (Medical University), Marymoncka street and Młociny subway - UKSW campuses and Ursynów subway - SGGW. A large share of city bike travel also includes cycling to the nearest subway station or transfer hub [Veturilo... 2019]. The system is fully station-based, which means that the bikes can only be rented or returned at the stations provided by attaching and removing the bicycle to/from a suitable holder [Jędrzejewski, Domaszewicz 2019]. In 2019, city bikes in Warsaw were rented out nearly 6 million times $(0.5$ million less than in 2018). The likely reason for this was the introduction of electric scooters hired by the minute, which are considered as an innovative shared means of transport to improve urban mobility.

\section{Conclusion}

Urban Shared urban mobility significantly reduces the number of private cars travelling in the city. This translates into a reduction in pollution and solves the problem of the first and last mile of journeys in cities. It is a chance for the effective use of the existing means of transport and resources. Modern cities strive to increase the share of walking, cycling and public transport in the structure of the traffic tasks. Improvement of conditions for pedestrian and bicycle traffic can be achieved by levelling barriers in pedestrian and bicycle traffic, traffic monitoring and the improvement of the available infrastructure. The main task of local authorities is to popularise shared means of transport in order to encourage residents to change their transport behaviour and to promote active mobility conducive to health. New transport solutions are the result of the development of a shared mobility market. The main factors influencing the growing share of shared means of transport include the increase in the ecological awareness of city dwellers, the implementation of the European Union's transport policy objective understood as supporting a low-emission economy, leading a healthier lifestyle, being fashion-driven, abandoning private car ownership for the sake of shared use, the development of new technologies, the improvement of the transport system in cities and the development of urban space in accordance with the needs of city dwellers. In Poland, urban bikes, available in 67 cities in Poland, constitute the largest group of shared means of transport. The analysis of both the length of bicycle paths (2011-2018) and the increase in the number of shared vehicles (2008-2019), presented in the study shows that the shared mobility market in Poland is a relatively new area, but with a high development dynamics. Bike sharing services are an alternative to car travel and support sustainable urban development. Future directions of research in the indicated area should concern the possibility of the implementation of shared services in smaller towns and cities, as well as indicate the reasons for the withdrawal of urban bicycle service from some towns and cities in Poland to prevent such phenomena. 


\section{Literature}

Chamier-Gliszczyński N., 2015, Zrównoważona mobilność miejska jako element planu transportowego, Logistyka, 4, pp. 107-116.

Docherty I., Marsden G., Anable J., 2018, The governance of smart mobility, Transportation Research Part A: Policy and Practice, 115, pp. 114-125.

Dominiak A., 2016, Pięciu chętnych na rower miejski, https://www.bip.krakow.pl/?news_id=73386 (access: 8.10.2019).

Gadziński J., Goras E, (eds.), 2019, Raport o stanie polskich miast. Transport i mobilność miejska, Obserwatorium polityki miejskiej, Instytut Rozwoju Miast i Regionów, Warszawa.

Główny Urząd Statystyczny (GUS), Bank Danych Lokalnych, https://bdl.stat.gov.pl/BDL/dane/podgrup/tablica (access: 12.10.2019).

Jędrzejewski A., Domaszewicz Z., 2019, Na progu przełomu: współdzielona mobilność w Polsce - lipiec 2019, https://smartride.pl/raport-na-progu-przelomu/ (access 10.11.2019).

Kos B., Krawczyk G., Tomanek R., 2018, Modelowanie mobilności w miastach, Wydawnictwo Uniwersytetu Ekonomicznego w Katowicach, Katowice.

Krajowa Polityka Miejska 2023, 2015, Ministerstwo Infrastruktury i Rozwoju, Warszawa.

Krysiuk C., Brdulak J., Banak M., 2015, Mobilność i komunikacja w miastach polskich, Technika Transportu Szynowego, 12, pp. 881-886.

Nosal K., Starowicz W., 2010, Wybrane zagadnienia zarządzania mobilnością, Transport Miejski i Regionalny, 3, pp. 26-31.

Przebieg szlaku, 2017, https://greenvelo.pl/70 (access: 16.10.2019).

Ramos É.M.S., Bergstad C.J., Chicco A., Diana M., 2020, Mobility styles and car sharing use in Europe: attitudes, behaviours, motives and sustainability,European Transport Research Review, 12(1), pp. 1-12.

Shaheen, S., Bell C., Cohen A., Yelchuru B., 2017, Travel behavior: Shared mobility and transportation equity (No. PL-18-007).

Sulmicki M., 2017, Mieć czy być w ruchu - IV Światowy Kongres Mobilności Współdzielonej, Mazowsze Studia Regionalne, 21, pp. 117-124.

Szołtysek J., 2011, Kreowanie mobilności mieszkańców miast, Wolters Kluwer, Warszawa.

Tarkowski M., 2016, Mobilność miejska jako wyzwanie strategicznego programowania rozwoju lokalnego - przykład Gdańska, Prace Komisji Geografii Komunikacji, 19(4), pp. 7-18.

The White Paper. Roadmap to a Single European Transport Area - Towards a competitive and resource efficient transport system, 2011, EC European Commission COM(2011)144, Brussels.

Veturilo-podsumowanie sezonu 2019, 2019, https://www.veturilo.waw.pl/veturilo-podsumowanie-sezonu-2019/ (access: 6.12.2019).

Warszawa lideruje $w$ dlugości ścieżek rowerowych, 2017, https://www.wnp.pl/logistyka/warszawa-lideruje-w-dlugosci-sciezek-rowerowych,303145.html (access: 6.11.2019).

The project is financed within the framework of the program of the Minister of Science and Higher Education under the name „Regional Excellence Initiative” in the years 2019-2022; project number 001/RID/2018/19; the amount of financing PLN 10,684,000.00. 